\title{
Using reproductive hormone concentrations from the muscle of white sharks Carcharodon carcharias to evaluate reproductive status in the Northwest Atlantic Ocean
}

\author{
Hannah J. Verkamp ${ }^{1, *}$, Gregory Skomal ${ }^{2}$, Megan Winton ${ }^{3}$, James A. Sulikowski ${ }^{4}$ \\ ${ }^{1}$ Department of Marine Sciences, University of New England, Biddeford, ME 04005, USA \\ ${ }^{2}$ Massachusetts Division of Marine Fisheries, New Bedford, MA 02744, USA \\ ${ }^{3}$ Atlantic White Shark Conservancy, Chatham, MA 02650, USA \\ ${ }^{4}$ School of Mathematical and Natural Sciences, Arizona State University, Glendale, AZ 85306, USA
}

\begin{abstract}
Novel, non-lethal approaches are needed to improve our current understanding of the reproductive biology and ecology of the white shark Carcharodon carcharias. Previous studies have demonstrated that concentrations of reproductive hormones in muscle tissue can be used as reliable indicators of reproductive status for many vertebrate species, including elasmobranchs. Here, we applied this method to assess the concentrations of testosterone $(\mathrm{T})$ and estradiol $\left(\mathrm{E}_{2}\right)$ in muscle biopsies from free-swimming white sharks at a known aggregation site off the coast of Cape Cod, Massachusetts (USA), in the Northwest Atlantic Ocean, to determine whether this technique could be used to evaluate the reproductive status of this species. A total of 14 muscle samples from 13 white sharks ( 7 males [1 sampled twice], 6 females), ranging in size from 3.3 to $4.2 \mathrm{~m}$ total length, were analyzed for this study. $\mathrm{T}$ and $\mathrm{E}_{2}$ were present in sufficient amounts to be quantified in 7 of the $8(87.5 \%)$ male and 1 of the $6(16.7 \%)$ female samples, respectively. As expected, most samples collected from immature individuals were below minimum detection thresholds. Hormone concentrations in males presumed to be adults were also generally low, suggesting these individuals were not actively producing sperm at the time of sample collection. Overall, the results herein are similar to those found in other species and indicate that concentrations of hormones in the skeletal muscle of subadult and adult white sharks can provide information on the reproductive status of individuals. This technique could have wide-ranging applications for the study of white shark reproduction in the future.
\end{abstract}

KEY WORDS: Elasmobranch $\cdot$ Reproduction $\cdot$ Estradiol $\cdot$ Testosterone

\section{INTRODUCTION}

Research conducted over the past 2 decades has greatly improved our understanding of the movements, diet, and behavior of white sharks Carcharodon carcharias, yet data on their reproductive biol-

*Corresponding author: hjverkamp@gmail.com ogy remains limited (Huveneers et al. 2018). Historically, reproductive studies have been hindered due to factors such as the low natural abundance of this apex predator (Francis 1996) and logistical difficulties associated with the capture and handling of large individuals. As a result, most information on

() The authors 2021. Open Access under Creative Commons by Attribution Licence. Use, distribution and reproduction are unrestricted. Authors and original publication must be credited. 
white shark reproduction has come from rare opportunistic sampling of incidentally captured individuals (Francis 1996, Pratt 1996, Saïdi et al. 2005) or indirect methods (e.g. satellite and acoustic telemetry) that have allowed researchers to make hypotheses regarding certain aspects of reproductive ecology (Jorgensen et al. 2010, Domeier \& Nasby-Lucas 2013, Skomal et al. 2017). Given the importance of reproductive data for the effective conservation of shark species, this deficit recently prompted experts to highlight reproduction as 1 of the top 10 research priorities for white sharks (Huveneers et al. 2018).

The analysis of reproductive hormone concentrations, such as estradiol $\left(\mathrm{E}_{2}\right)$ and testosterone $(\mathrm{T})$, in body tissues is a nonlethal approach to elasmobranch reproductive studies that can be used to inform characteristics such as life stage, reproductive status, the timing of reproductive events, and how species are using a particular habitat (Gelsleichter \& Evans 2012, Awruch 2013, Sulikowski et al. 2016). In female elasmobranchs, $\mathrm{E}_{2}$ is primarily associated with regulating vitellogenesis, while in males, $\mathrm{T}$ functions primarily in spermatogenesis and sperm maturation (Awruch 2013). Circulating concentrations of these hormones, obtained from blood plasma, have previously been used to nonlethally assess reproductive status in white sharks (Sulikowski et al. 2012). However, this approach has not been widely applied, in part because obtaining plasma samples for studies of this nature is logistically problematic for many research groups. Alternatively, quantifying reproductive hormones in muscle tissue, which can be collected from free-swimming individuals, has also been shown to be effective in determining reproductive state across a range of aquatic vertebrates, including teleosts (Heppell \& Sullivan 2000), chimeras (Barnett et al. 2009), and elasmobranchs (Prohaska et al. 2013). For example, in the little skate Leucoraja erinacea, spiny dogfish Squalus acanthias, and Atlantic sharpnose shark Rhizoprionodon terraenovae, concentrations of reproductive hormones in muscle tissue are generally related to those in plasma and can be used as indicators of reproductive status (Prohaska et al. 2013). Here, our objective was to apply this method to white sharks for the first time to determine whether concentrations could be quantified and used to evaluate the reproductive stage of this species in the coastal waters of Cape Cod, Massachusetts (USA).

\section{MATERIALS AND METHODS}

Muscle tissue was sampled from free-swimming white sharks near Cape Cod, Massachusetts, in the Northwest Atlantic Ocean (Fig. 1), between August and October of 2017 and 2018 as part of the Massachusetts Division of Marine Fisheries directed white shark tagging program. Samples were collected from sharks swimming at the surface using a custommade, marine-grade 316 stainless steel biopsy needle (Amherst Machine) attached to a hand-held tagging pole (Skomal et al. 2017). The biopsy needle was $11.5 \mathrm{~cm}$ long and $1 \mathrm{~cm}$ in diameter, with a beveled cutting edge, internal retention barb, and a single vent to allow water to escape. Underwater video of each shark sampled was used to determine sex and identify individuals. The total length (TL) of each individual was visually estimated to the nearest $0.3 \mathrm{~m}$, and life history stage was assigned as described by Skomal et al. (2017) (for males, juvenile: $<3 \mathrm{~m}$, subadult: $3.0-3.5 \mathrm{~m}$, adult: $\geq 3.5 \mathrm{~m}$; for females, juvenile: $<3 \mathrm{~m}$, subadult: $3.0-4.8 \mathrm{~m}$, adult: $\geq 4.8 \mathrm{~m}$ ). Juveniles and subadults were considered immature, while adults were considered sexually mature. Mus-

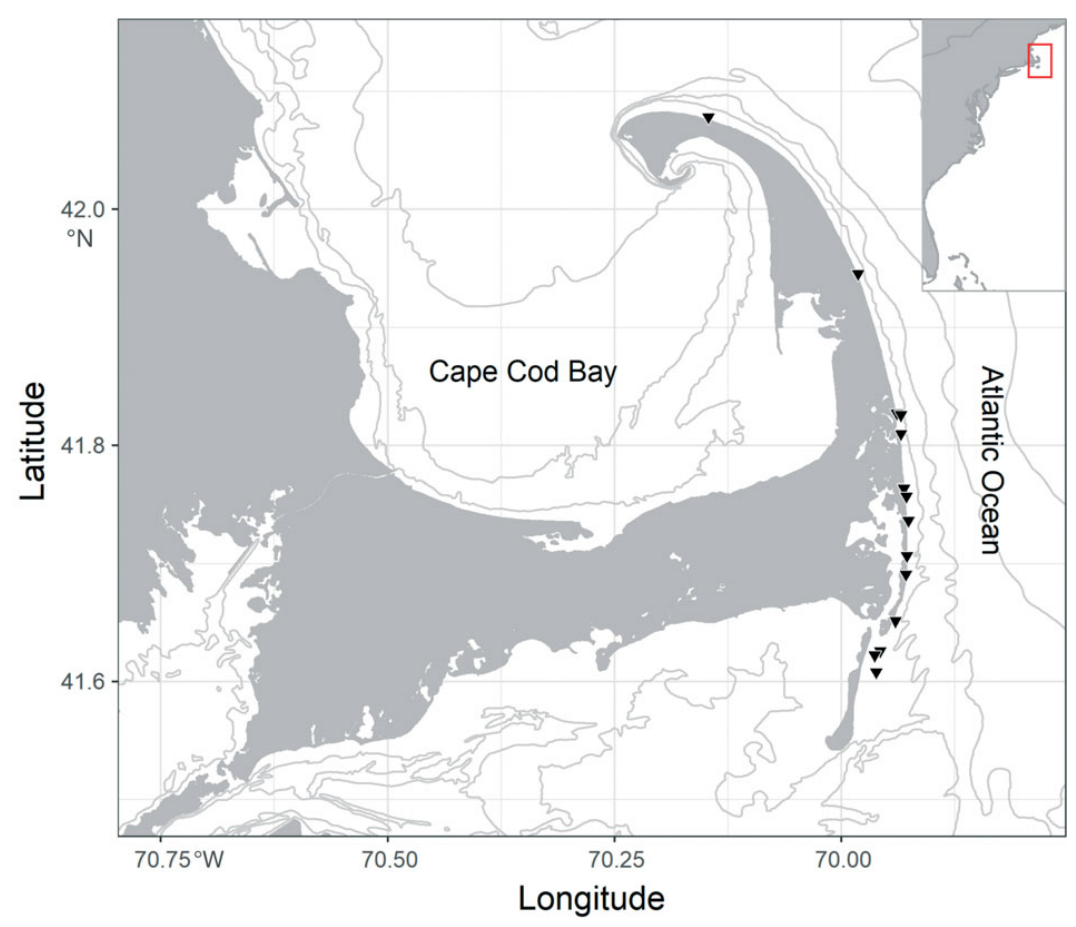

Fig. 1. Biopsy locations (black triangles) for white sharks sampled in this study 
cle samples were frozen and shipped on ice to the University of New England (Biddeford, ME), where they remained frozen at $-20^{\circ} \mathrm{C}$ until processing.

$\mathrm{T}$ and $\mathrm{E}_{2}$ were extracted from the muscle tissue of males and females, respectively, following ether extraction protocols modified from those used for plasma by Sulikowski et al. (2012). Ether, which has been used to extract reproductive hormones from the muscle of spotted ratfish Hydrolagus colliei (Barnett et al. 2009), was chosen based on preliminary extractions; this solvent resulted in higher recoveries of hormones than a chloroform-methanol solution (Prohaska et al. 2013). Samples were thawed on ice, and white muscle tissue was excised, weighed, and transferred to a borosilicate tube. Phosphate-buffered saline (PBS) was added in a ratio of $1 \mathrm{~g}$ muscle to $1 \mathrm{ml}$ PBS, and the samples were homogenized using a Kinematica Polytron PT 10-35. To account for procedural loss, homogenate was spiked with approximately 1000 counts $\mathrm{min}^{-1}$ of the appropriate tritiated hormone $\left(1,2,6,7,{ }^{3} \mathrm{H}-\mathrm{T}\right.$ or $2,4,6,7,16,17,{ }^{3} \mathrm{H}-\mathrm{E}_{2}$; Perkin Elmer Life Sciences). Each homogenate sample was then extracted 4 times with $5 \mathrm{ml}$ of diethyl ether (ACS grade) and snap-frozen in a dry ice and acetone (ACS grade) bath. The aqueous phase was decanted into a second borosilicate tube and evaporated at $37^{\circ} \mathrm{C}$ in a heat block under a stream of nitrogen. Isolated hormones were reconstituted in $250 \mu \mathrm{l}$ of PBS with $0.1 \%$ gelatin and stored at $4{ }^{\circ} \mathrm{C}$.

Hormone concentrations were determined following radioimmunoassay methods modified from Sulikowski et al. (2004). Antisera (provided by Dr. Gordon Niswender, Colorado State, Fort Collins, CO) were diluted in PBS with $0.1 \%$ gelatin to final concentrations of $1: 17600$ and 1:60 800 for $T$ and $E_{2}$, respectively. A Tri-Carb 2900TR liquid scintillation counter (Perkin Elmer Life Sciences) was used to calculate radioactivity. The inter-assay coefficients of variation were 15 and $15 \%$, and the mean intraassay coefficients of variation were 11 and $12 \%$ for $\mathrm{T}$ and $\mathrm{E}_{2}$, respectively.

\section{RESULTS}

Muscle samples were collected from 13 individual white sharks (6 females, 7 males), with estimated TLs ranging from 3.3 to $4.2 \mathrm{~m}$ (Table 1). One male (B1703) was biopsied twice, once in August 2017 and again in October
2018, resulting in a total of 8 male samples. All female biopsies were collected in the month of October across the 2 sampling years. Based on estimated TLs, all sampled females were likely subadults (mean $\pm \mathrm{SD}: 3.8 \pm 0.36 \mathrm{~m} \mathrm{TL}$ ); with the exception of 1 subadult, all males sampled were likely adults $(3.7 \pm$ $0.27 \mathrm{~cm} \mathrm{TL}$; Table 1). The mean recoveries for $\mathrm{T}$ and $\mathrm{E}_{2}$ from muscle tissue were 73.9 and $72.3 \%$, respectively. $\mathrm{E}_{2}$ was detected (minimum detection limit: 5 pg $E_{2}$ per $100 \mu \mathrm{l}$ extract) in 1 of the 6 extracted female samples, albeit at a very low level (B1710: $29.8 \mathrm{pg} \mathrm{E}_{2} \mathrm{~g}^{-1}$ muscle). $\mathrm{T}$ was quantified in 7 of 8 male samples (minimum detection limit: $6.25 \mathrm{pg} \mathrm{T}$ per $100 \mu$ l extract) (Table 1). T levels were generally low (range 40.48-182.79 $\mathrm{pg} \mathrm{T} \mathrm{g}^{-1}$ muscle), with the notable exception of the second sample from the individual that was biopsied in consecutive years, which had a $\mathrm{T}$ level of $1070.94 \mathrm{pg} \mathrm{T} \mathrm{g}^{-1}$ muscle in October 2018 (Fig. 2).

\section{DISCUSSION}

In this study, we extracted and quantified $\mathrm{E}_{2}$ and $\mathrm{T}$ from the muscle tissue of subadult female and subadult and adult male white sharks, respectively. The results of this study are consistent with our current understanding of the role of reproductive hormones in sharks, are comparable to concentrations previously reported for elasmobranch skeletal muscle, and follow general trends observed across life stages in other vertebrate species. This illustrates that assessing reproductive hormone concentrations

Table 1. Biopsy data for individual white sharks. Life stages were based on Skomal et al. (2017). TL: total length; $\mathrm{E}_{2}$ : estradiol; T: testosterone $;<$ min: below the minimum detectable concentration of the assay

\begin{tabular}{|c|c|c|c|c|c|}
\hline Sex & ID & $\begin{array}{c}\text { Date } \\
\text { (mm/dd/yy) }\end{array}$ & $\begin{array}{l}\text { Estimated } \\
\text { TL (m) }\end{array}$ & $\begin{array}{l}\text { Estimated } \\
\text { life stage }\end{array}$ & $\begin{array}{c}\mathrm{E}_{2} \text { (females) } \\
\text { or T (males) } \\
\text { (pg g }{ }^{-1} \text { muscle) }\end{array}$ \\
\hline Female & $\begin{array}{l}\text { B1707 } \\
\text { B1708 } \\
\text { B1710 } \\
\text { B1711 } \\
\text { B1712 } \\
\text { B1715 }\end{array}$ & $\begin{array}{c}10 / 5 / 17 \\
10 / 10 / 17 \\
10 / 20 / 17 \\
10 / 20 / 17 \\
10 / 27 / 17 \\
10 / 31 / 18\end{array}$ & $\begin{array}{l}3.6 \\
4.2 \\
3.6 \\
3.9 \\
3.3 \\
4.2\end{array}$ & $\begin{array}{l}\text { Subadult } \\
\text { Subadult } \\
\text { Subadult } \\
\text { Subadult } \\
\text { Subadult } \\
\text { Subadult }\end{array}$ & $\begin{array}{l}<\min \\
<\min \\
29.80 \\
<\min \\
<\min \\
<\min \end{array}$ \\
\hline Male & $\begin{array}{c}\text { B1701 } \\
\text { B1703A } \\
\text { B1704 } \\
\text { B1705 } \\
\text { B1706 } \\
\text { B1709 } \\
\text { B1713 } \\
\text { B1703B }\end{array}$ & $\begin{array}{c}8 / 7 / 17 \\
8 / 17 / 17 \\
8 / 17 / 17 \\
9 / 13 / 17 \\
10 / 2 / 17 \\
10 / 18 / 17 \\
8 / 9 / 18 \\
10 / 19 / 18\end{array}$ & $\begin{array}{l}3.3 \\
3.6 \\
3.9 \\
3.6 \\
3.9 \\
4.2 \\
3.6 \\
3.6\end{array}$ & $\begin{array}{c}\text { Subadult } \\
\text { Adult } \\
\text { Adult } \\
\text { Adult } \\
\text { Adult } \\
\text { Adult } \\
\text { Adult } \\
\text { Adult }\end{array}$ & $\begin{array}{c}182.79 \\
40.48 \\
165.49 \\
<\min \\
46.61 \\
157.06 \\
153.12 \\
1070.94\end{array}$ \\
\hline
\end{tabular}




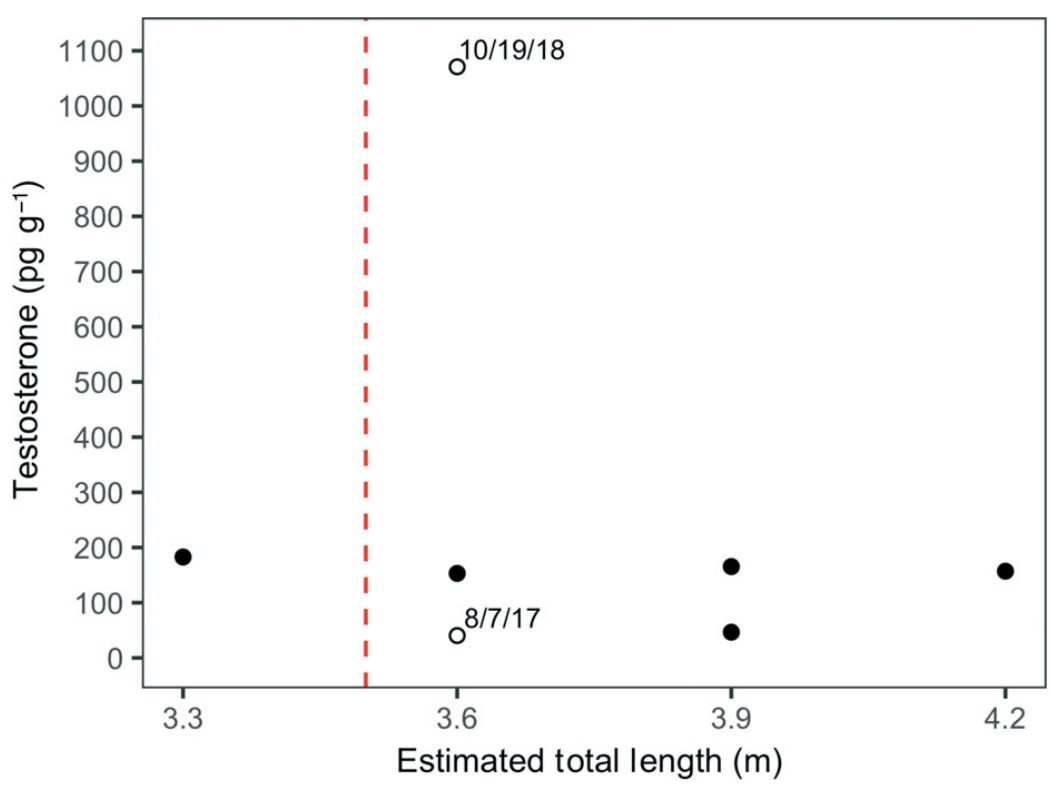

Fig. 2. Muscle concentrations of testosterone versus the estimated total length of male white sharks. The open circles represent data points for different samples collected from the same individual with associated dates of collection (given as $\mathrm{mm} / \mathrm{dd} / \mathrm{yy}$ ). The red dashed line indicates the estimated size at maturity

in muscle tissue, which can be collected from freeswimming white sharks, is a feasible, non-invasive method to gain information on the reproductive biology of this species, which remains largely unknown (reviewed by Huveneers et al. 2018).

$\mathrm{E}_{2}$ concentrations in the majority of female samples were undetectable, and this is likely a reflection of the maturity status of the individuals. For example, very low, often undetectable, $\mathrm{E}_{2}$ is characteristic of immature female sharks (Awruch 2013), and many studies have reported undetectable/minimum hormone values for both immature females and mature females that are not actively undergoing vitellogenesis (e.g. muscle, Prohaska et al. 2013; plasma, Sulikowski et al. 2016). Sulikowski et al. (2012) were similarly unable to quantify $\mathrm{E}_{2}$ in the plasma of immature female white sharks, while mature females displayed higher $\mathrm{E}_{2}$ concentrations. Muscle levels of this hormone showed a similar pattern in Atlantic sharpnose sharks and little skates (Prohaska et al. 2013). As all female white sharks in this study were likely immature based on their estimated sizes, low or undetectable $\mathrm{E}_{2}$ concentrations were expected. This result is further supported by the observation that none of these individuals had scars or wounds indicative of recent mating. In addition, given that the high sensitivity of our assay was able to detect the very low $\mathrm{E}_{2}$ concentration in 1 subadult female, this method can be used in the future to study mature females, as adults produce larger quantities of this hormone during certain stages of their reproductive cycle (e.g. Awruch 2013, Prohaska et al. 2013). Large, presumably mature females have previously been documented at the sampling site (Skomal et al. 2017), and future studies should prioritize collecting muscle samples from such individuals.

In contrast to females, the majority of males sampled were considered adults based on their estimated sizes (Skomal et al. 2017). The muscle $T$ levels of all males sampled in this study were much lower than those previously reported in the plasma of mature male white sharks (range 2519.12-7483.62 $\mathrm{pg} \mathrm{ml}^{-1}$ plasma), and all but 2 were lower than those in immature males (range 171.92$337.79 \mathrm{pg} \mathrm{ml}^{-1}$ plasma) (Sulikowski et al. 2012). This disparity is likely associated with differences in the quantity of hormones present in different tissues, as concentrations in muscle are generally considerably lower than those in plasma (Prohaska et al. 2013).

The low $\mathrm{T}$ levels that we observed can be attributed to a number of factors. First, given considerable individual variation in size at maturity (Pratt 1996), it is possible that males classified as adults based on TL had not reached maturity. However, visual assessment of clasper length and rigidity from underwater video footage collected at the time of sampling indicated that all males, including the individual classified as a subadult, had well-developed claspers that appeared to be calcified and were probably indicative of maturity (Pratt 1996). Alternatively, it is likely that the low T levels observed could be associated with time of sampling (early August to mid-October) as it relates to the reproductive cycle, as low $\mathrm{T}$ is generally found in males that are not actively undergoing spermatogenesis (Gelsleichter \& Evans 2012). The successively sampled male in this study (B1703) provided an interesting observation of variability over time that suggests $\mathrm{T}$ concentrations begin to rise in the fall. In some elasmobranch species, $T$ levels peak several months prior to mating (when spermatogenic activity is highest), decrease and remain low throughout the mating season, and subsequently begin to increase again after the mating period (Manire \& Rasmussen 1997). If this pattern holds 
for white sharks, our observations support the hypothesis that this species mates in the spring and summer months in the Northwest Atlantic Ocean (Pratt 1996, Skomal et al. 2017), and it could also be indicative of post-spermatogenesis sperm storage. Sperm storage has been well documented in elasmobranchs, including the white shark (Pratt \& Tanaka 1994), and Domeier (2012) suggested that low plasma $\mathrm{T}$ levels measured in reproductively active male white sharks sampled off Guadalupe Island, Mexico, a purported breeding area, could be indicative of post-spermatogenesis sperm storage. However, without additional sampling, we cannot entirely rule out that the difference in $\mathrm{T}$ found in successive samples from B1703 reflected a change in maturity state between years (Prohaska et al. 2013), variation associated with individual reproductive behaviors, or dominance effects (Henningsen et al. 2008), which have been largely unexplored in wild elasmobranch populations. Future studies should evaluate how muscle T levels fluctuate over time and among individuals in relation to reproductive events in this species.

In conclusion, the results herein provide the first use of muscle tissue to assess reproductive status of white sharks at a known aggregation site in the Northwest Atlantic. The results of our study suggest that this method is a feasible, non-invasive approach that can be applied to white sharks to gain insight into the reproductive biology and ecology of this species, which remains poorly understood. Some useful applications may include using muscle hormone concentrations to assess individual variability in reproductive events or maturity as well as to evaluate habitat use as it relates to reproduction. Future studies should prioritize collecting muscle samples from individuals of varying life history stages throughout the year for both sexes to evaluate how concentrations of hormones change throughout maturity and a complete reproductive cycle.

Acknowledgements. We thank the Atlantic White Shark Conservancy, Massachusetts Division of Marine Fisheries (MA DMF), and the University of New England Marine Science Center (MSC) for providing funding and other support for this project. We thank J. Chisholm for initial identification of sampled sharks. Samples were collected under permits issued by the MA DMF.

\section{LITERATURE CITED}

Awruch CA (2013) Reproductive endocrinology in chondrichthyans: the present and the future. Gen Comp Endocrinol 192:60-70
Barnett LAK, Earley RL, Ebert DA, Cailliet GM (2009) Maturity, fecundity, and reproductive cycle of the spotted ratfish, Hydrolagus colliei. Mar Biol 156:301-316

Domeier M (2012) A new life-history hypothesis for white sharks, Carcharodon carcharias, in the Northeastern Pacific. In: Domeier M (ed) Global perspectives on the biology and life history of the white shark. CRC Press, Boca Raton, FL, p 199-224

* Domeier ML, Nasby-Lucas N (2013) Two-year migration of adult female white sharks (Carcharodon carcharias) reveals widely separated nursery areas and conservation concerns. Anim Biotelem 1:2

Francis MP (1996) Observations on a pregnant white shark with a review of reproductive biology. In: Klimley AP, Ainley DG (eds) Great white sharks: the biology of Carcharodon carcharias. Academic Press, San Diego, CA, p 157-172

Gelsleichter J, Evans AN (2012) Hormonal regulation of elasmobranch physiology. In: Carrier JC, Musick JA, Heithaus MR (eds) Biology of sharks and their relatives, $2^{\text {nd }}$ edn. CRC Press, Boca Raton, FL, p 313-338

*Henningsen AD, Murru FL, Rasmussen LEL, Whitaker BR, Violetta GC (2008) Serum levels of reproductive steroid hormones in captive sand tiger sharks, Carcharias taurus (Rafinesque), and comments on their relation to sexual conflicts. Fish Physiol Biochem 34:437-446

*Heppell SA, Sullivan CV (2000) Identification of gender and reproductive maturity in the absence of gonads: muscle tissue levels of sex steroids and vitellogenin in gag (Mycteroperca microlepis). Can J Fish Aquat Sci 57:148-159

*Huveneers C, Apps K, Becerril-García EE, Bruce B and others (2018) Future research directions on the 'elusive' white shark. Front Mar Sci 5:455

* Jorgensen SJ, Reeb CA, Chapple TK, Anderson S and others (2010) Philopatry and migration of Pacific white sharks. Proc R Soc B 277:679-688

*Manire CA, Rasmussen LEL (1997) Serum concentrations of steroid hormones in the mature male bonnethead shark, Sphyrna tiburo. Gen Comp Endocrinol 107:414-420

Pratt HL (1996) Reproduction in the male white shark. In: Klimley AP, Ainley DG (eds) Great white sharks: the biology of Carcharodon carcharias. Academic Press, San Diego, CA, p 131-138

* Pratt HL Jr, Tanaka S (1994) Sperm storage in male elasmobranchs: a description and survey. J Morphol 219:297-308

* Prohaska BK, Tsang PCW, Driggers WB, Hoffmayer ER, Wheeler CR, Brown AC, Sulikowski JA (2013) Assessing reproductive status in elasmobranch fishes using steroid hormones extracted from skeletal muscle tissue. Conserv Physiol 1:cot028

Saïdi B, Bradaï MN, Bouaïn A, Guélorget O, Capapé C (2005) Capture of a pregnant female white shark, Carcharodon carcharias (Lamnidae) in the Gulf of Gabès (southern Tunisia, central Mediterranean) with comments on oophagy in sharks. Cybium 29:303-307

Skomal GB, Braun CD, Chisholm JH, Thorrold SR (2017) Movements of the white shark Carcharodon carcharias in the North Atlantic Ocean. Mar Ecol Prog Ser 580: $1-16$

Sulikowski JA, Tsang PCW, Huntting Howell W (2004) An annual cycle of steroid hormone concentrations and gonad development in the winter skate, Leucoraja ocellata, from the western Gulf of Maine. Mar Biol 144: $845-853$ 
Sulikowski J, Williams L, Domeier M (2012) The use of a nonlethal technique to assess the reproductive biology of the white shark, Carcharodon carcharias. In: Domeier ML (ed) Global perspectives on the biology and life history of the white shark. CRC Press, Boca Raton, FL, p 467-476

Editorial responsibility: Austin Gallagher,

Herndon, Virginia, USA

Reviewed by: 2 anonymous referees
Sulikowski JA, Wheeler CR, Gallagher AJ, Prohaska BK, Langan JA, Hammerschlag N (2016) Seasonal and lifestage variation in the reproductive ecology of a marine apex predator, the tiger shark Galeocerdo cuvier, at a protected female-dominated site. Aquat Biol 24: 175-184

Submitted: July 22, 2020

Accepted: December 22, 2020

Proofs received from author(s): February 28, 2021 